\title{
TIAF1 Gene
}

National Cancer Institute

\section{Source}

National Cancer Institute. TIAF1 Gene. NCI Thesaurus. Code C101372.

This gene plays a role in the regulation of apoptosis. 